\section{CarakaTani \\ Journal of Sustainable Agriculture \\ ISSN 2613-9456 (Print) 2599-2570 (Online)}

\title{
The Characterization of Black Pigeon Pea (Cajanus cajan) in Gunungkidul, Yogyakarta
}

\author{
Endang Yuniastuti*, Sukaya, Lintang Chandra Dewi and Marshelina Noor Indah Delfianti
}

Department of Agrotechnology, Faculty of Agriculture, Universitas Sebelas Maret, Surakarta, Indonesia

*Corresponding author: yuniatutisibuea@staff.uns.ac.id

\begin{abstract}
Pigeon pea (Cajanus cajan) is potential as an alternative source of protein other than soybeans and is tolerant to dry conditions, but the cultivation of this plant has not been intensively carried out in Indonesia. This research aims to explore the characteristics of black pigeon pea and investigate the producing areas of black pigeon peas in Gunungkidul. Based on the field survey, 30 types of black pigeon peas were found. They were located in Pringapus and Klopoloro 1 Hamlets. This research was conducted on March-June 2018 in Yogyakarta. The observation variables in this study include research environmental condition and plant morphology, for examples, stems, leaves, flowers, pods and seeds. Morphological data were analyzed using NTSYS program. The results show that the height of pigeon pea plants ranged from $63 \mathrm{~cm}$ to $176 \mathrm{~cm}$, the number of branches ranged from 18 to 35 , the colors of stem were green to purple and the stem thickness was $>13 \mathrm{~mm}$. The similarity of the coefficient value of pigeon peas in Pringapus ranged between $84 \%$ and $95 \%$, while the similarity in Klopoloro 1 varied between $80 \%$ and $97 \%$.
\end{abstract}

Keywords: diversity; Gude beans; morphological character

Cite this as: Yuniastuti, E., Sukaya, Dewi, L. C., \& Delfianti, M. N. I. (2020). The Characterization of Black Pigeon Pea (Cajanus cajan) in Gunungkidul, Yogyakarta. Caraka Tani: Journal of Sustainable Agriculture, 35(1), 78-88. doi: http://dx.doi.org/10.20961/carakatani.v35i1.28400

\section{INTRODUCTION}

Pigeon pea (local name: kacang gude) is a perennial of the family leguminosae. It is widely cultivated using monoculture method in several regions in Indonesia such as Yogyakarta, Wonogiri (Central Java), Tulungagung (East Java), Madura (East Java) and the locations due to its edible seeds (Primiani and Pujiati, 2016; Ersam et al., 2018). According to Maintang et al. (2014), pigeon pea has not been able to act as a cash crop plant, so this plant can be developed as a side plant, which is planted in the garden, or intercropped with other plants. In the other words, it has not been developed intensively in Indonesia.

In fact, pigeon pea is the main source of nutrition (protein) (Burns et al., 2001) and contains vitamin B (Fu et al., 2006). Pigeon pea has a quite good nutrition as other nuts. Every
$100 \mathrm{~g}$ of pigeon peas contain $336 \mathrm{kcal}$ of energy; $20.7 \mathrm{~g}$ of protein; $62 \mathrm{~g}$ of carbohydrates; $1.4 \mathrm{~g}$ of fat; $12.2 \mathrm{~g}$ of water content (Mengesha, 1979; Utami et al., 2015).

Pigeon pea can grow in an infertile and relatively dry land (Varshney et al., 2012) because of their deep roots (Odeny, 2007). The deep rooting of this plant does not interfere with the absorption of other plants so pigeon pea can be intercropped (Sheahan, 2012). According to Cook et al. (2005) and Khoiriyah et al. (2018), pigeon pea does not need much water and is resistant to high rainfall intensity. It can live in a dry condition because it can adapt to the long rooting system. The optimum soil $\mathrm{pH}$ for growth is $4.5-$ 8.4.

For sustainable agriculture, pigeon pea (Cajanus cajan) is potential to substitute protein

\footnotetext{
* Received for publication March 5, 2019

Accepted after corrections January 6, 2020
} 
sourced from soybeans and is tolerant to dry condition, however, the cultivation of the plant has not been carried out intensively in Indonesia. Despite of this fact, traditional varieties are generally intercropped with food crops such as maize, sorghum, beans, cowpea and non-food crops such as cotton. The minimum input and the long duration of local landraces make the crop particularly suitable for smallholder farming system. Pigeon pea is nutritionally well-balanced and is an excellent source of proteins (20-30\%) (Adjei-Nsiah, 2012). According to Cisanet (2015), pigeon pea's deep root system enables it to exploit moisture from deeper soil layers, making it well-suited for drier areas of ESA (Eastern and Southern African).

Edible parts of pigeon pea such as leaves, stem and pod are commonly used for the treatments of wounds, aphtha, bedsores and malaria, as well as diet-induced hypercholesterolemia ( $\mathrm{Wu}$ et al., 2009). These are due to the antioxidant content in the leaves of pigeon pea. Other parts of the pigeon pea have more or less the same benefits (Dayal et al., 2003; Waheed et al., 2006; Kundu et al., 2008). That is because other parts of the plant also contain the same antioxidants (Reddy et al., 2005; Niveditha et al., 2012; Khoiriyah et al., 2018; Gitiara et al., 2019).

Based on the statements above, researchers are interested in exploring pigeon pea from nature. The exploration aims to find out the character of pigeon pea according to the morphological of plants and collect information about the existing pigeon pea in nature (Yuniastuti et al., 2016; Yuniastuti et al., 2018). After performing the efforts, the diversity of pigeon pea was obtained, and thus, domestication of pigeon pea from nature could be done and this plant could be optimally cultivatited.

\section{MATERIALS AND METHOD}

This research was conducted in March-June 2018 in Pringapus and Klopoloro 1 Hamlets, Giripanggung Village, Tepus Sub-district, Gunungkidul Regency, Yogyakarta. The materials for observation were 30 pigeon pea plants found in Pringapus and Klopoloro 1. A total of fifteen (15) plants from each sample were taken, by considering genotype similarity. The tools used for this study were pigeon pea descriptor guidelines issued by IPGRI (International Plant Genetic Resources Institute)
(Bettencourt et al., 1989), Global Positioning System (GPS), meters, stationery, plastic bags, raffia, scissors and camera for documentation.

This exploration was carried out by survey method to find out the producing areas of black pigeon peas in Gunungkidul. The samples were selected using purposive sampling technique. The selection was based on the criteria of the plants such as having the required parts, having more than 10 pods (per plant), mature and having a blooming flower. The observation variables include general conditions of the research area, stem, leaf, flower, pod and seed morphology.

Data were collected using various techniques, comprising observation, recording and documentation. The data obtained took forms of scores (IBPGR, 1983), which were then transformed into binary forms to be further inputted into NTSYS (Numerical Taxonomy and Multivariate Analys System) software version 2.02i. The method of Similarity for Qualitative Data (SimQual) with SM (Simple Matching) similarity coefficient was applied in this study. Sequential Hierarchical Agglomerative Non-Overlapping (SHAN) and Nested Clustering were also applied, with the results based on the inputted matrix data.

In the next step, clustering plant samples was carried out using Unweighted Pair Group Method Arithmatic Average (UPGMA). This cluster analysis aimed to classify samples based on characteristic similarities (Darcan and Badur, 2012). The results of the analysis were presented to dendrogram so that the morphological diversity of the pigeon pea could be identified. In addition to cluster analysis, descriptive analysis and chisquare analysis were conducted using Microsoft Excel 2010. Chi-square analysis was performed to determine the influence of place on each observation variable. Color analysis was carried out using the Royal Horticulture Society (RHS) color chart Edition V version 2.

\section{RESULTS AND DISCUSSION}

\section{General condition of research location}

The research sites were two places in Giripanggung Village, Tepus Sub-district, Gunungkidul Regency, Yogyakarta. Pringapus is located between $8^{\circ} 5^{\prime} 40.6 "$ South Latitude and $110^{\circ} 4$ '8.9" East Longitude (315 meter above sea level, $\mathrm{m}$ a.s.1.), while Klopoloro 1 is located between $8^{\circ} 7^{\prime} 21.1^{\prime \prime}$ South Latitude and $110^{\circ} 41^{\prime} 40$. 75" East Longitude (287 m a.s.l.). Gunungkidul 
has an average rainfall of $1,881.94 \mathrm{~mm}^{\text {year }}{ }^{-1}$ (BPS Gunungkidul, 2015), daily air temperature of $27.7^{\circ} \mathrm{C}$ and air humidity around $80-85 \%$.

Tepus Sub-district is included in the southern zone known as the Gunung Sewu karst zone with an altitude of $100-300 \mathrm{~m}$ a.s.l. This area is dominated by karst hills and there are many natural caves and underground rivers. The type of soil in the southern region is Mediterranean soil which is formed from the weathering of limestone. This causes land conditions in the southern region to be infertile so that agricultural cultivation is less optimal.

\section{Stem morpholgy}

Pigeon pea Pringapus plant height was dominated by a score of 1 (very low) with a range of $<86 \mathrm{~cm}$, while Klopoloro 1 was dominated by a score of 5 (very high) with a range of $>229 \mathrm{~cm}$. Based on the results of Chi-square analysis, $\mathrm{X}^{2}$ count (13.558) $>X^{2}$ table (9.487). These show the influence of place on the plant height. Purwanto (2007) revealed that the pigeon pea plant is a shrub with woody stems and has a height ranging from 50-500 cm. Krisnawati (2005) also revealed that pigeon pea plants can reach $250 \mathrm{~cm}$ in height and branch off (Table 1).

Table 1. The diversity of morphological characters of pigeon pea stem in Pringapus and Klopoloro 1

\begin{tabular}{lcccccc}
\hline \multirow{2}{*}{\multicolumn{1}{c}{ Character }} & \multicolumn{2}{c}{ Location } & \multicolumn{2}{c}{ Score } & \multicolumn{2}{c}{ Chi-square analysis } \\
\cline { 2 - 7 } & Pringapus & Klopoloro 1 & Pringapus & Klopoloro 1 & $X^{2}$ count & $\mathrm{X}^{2}$ table \\
\hline Plant height $(\mathrm{cm})$ & $40-88$ & $50-276$ & 1 & 3 & 13.558 & 9.487 \\
Number of branches & $9-53$ & $4-49$ & 2 & 2 & 2.033 & 9.487 \\
Stem color & Green & Sun red & 1 & 2 & 12.596 & 9.487 \\
Stem thickness (mm) & $-15.923-$ & $-11.464-$ & 3 & 3 & 02.202 & 9.487 \\
& 36.624 & 27.707 & & & & \\
\hline
\end{tabular}

Note: The value of $X^{2}$ count $>X^{2}$ table means there is a correlation. The value of $X^{2}$ count $<X^{2}$ table means there is no correlation (Level 5\%, df: 4)

Table 1 presents that the number of branches of plants found in both places was mostly scored 2 (little), ranging from 15-24. The results of Chisquare analysis demon-strates the value of $\mathrm{X}^{2}$ count $(2.033)<\mathrm{X}^{2}$ table $(9.487)$. This shows that there is no relationship between the place and the number of branches. According to Gitiara et al. (2019), pigeon pea plants vary in the number of primary and secondary branches. Kumar et al. (2010) have notified the branching of pigeon pea plants also depends on the plant spacing. Wide spacing can form more branching (Table 1).

The dominant color of pigeon pea stem in Pringapus was green (score 1). Green in the RHS was indicated by 144B code. The dominant color of pigeon pea stem in Klopoloro 1 was sun red (score 2). Sun red in the RHS was indicated by 178B code (Figure 1). Chi-square analysis resulted in $\mathrm{X}^{2}$ count (12.596) > $\mathrm{X}^{2}$ table (9.487). This condition proves that place contributes to the color of the stem. Planting density of pigeon pea can be used as an important management tool to improve leaf area index, light interception, radiation use efficiency and hence productivity (Worku and Demisie, 2012). Irawan and Kartika (2008) have revealed that light intensity affects the color of the stem surface, where pigment regulation is in the epidermal or parenchymal tissues. Anthocyanin pigments can play a role in determining stem color. Kimani et al. (2001) have mentioned that the pigeon pea stem is generally green to purple.

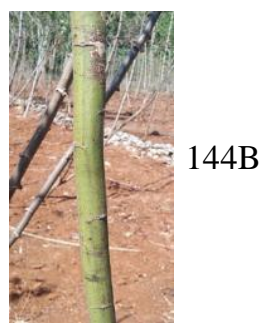

a

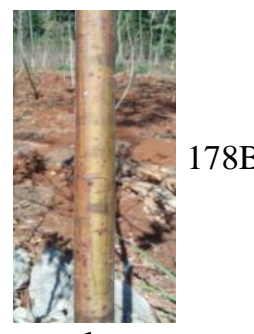

b

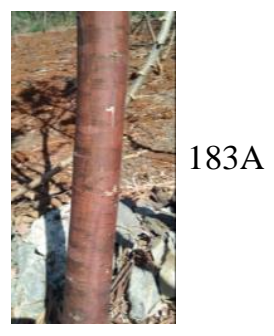

c

Figure 1. Green stem of pigeon pea (a), sun red stem of pigeon pea (b), purple stem of pigeon pea (c). In RHS color cart: 144B (part of turquoise-green colour), 178B (part of browngrey color), 183A (part of brown-grey color) 
The pigeon pea stem thickness in Pringapus is dominated by a score of 2 (Thin) with a range of 16.5-21.52 $\mathrm{mm}$ and a score of 3 (Medium) with a range of 21.53-26.56 mm, while in Klopoloro 1 it is dominated by a score of 2 (Thin). Based on the Table 2 of Chi-square analysis, $\mathrm{X}^{2}$ count (2.202) $<\mathrm{X}^{2}$ table (9.487). This demonstrates that place does not correlate with the thickness of the stem. Porter and Bidlack (2011) have confirmed that the diameter of pigeon pea stem can reach up to 15 $\mathrm{cm}$ (Table 1). The dendrogram analysis grouped stems of pigeon peas found in Pringapus due to similar characteristics of plant height and stem color, while the analysis of stem morphology of the plants found in Klopoloro 1 categorized the stems because of the similarity of the stem color characters.

\section{Leaf morphology}

The width of pigeon pea leaves in Pringapus was dominated by a score of 2 (Narrow) with a width range of $16.47-21.58 \mathrm{~mm}^{2}$, while in Klopoloro 1, it was dominated by a score of 3 (Medium). Table 2 of Chi-square analysis shows $\mathrm{X}^{2}$ count $(9.352)<\mathrm{X}^{2}$ table $(9.487)$. This confirms that place and the leaf width do not show any correlation. According to Sheahan (2012), pigeon pea leaves are 5-10 cm long and 2-4 cm wide.

Table 2. The diversity of morphological characters of black pigeon pea leaf in Pringapus and Klopoloro 1

\begin{tabular}{lcccccc}
\hline \multirow{2}{*}{ Character } & \multicolumn{2}{c}{ Location } & \multicolumn{2}{c}{ Score } & \multicolumn{2}{c}{ Chi-square analysis } \\
\cline { 2 - 7 } & Pringapus & Klopoloro 1 & Pringapus & Klopoloro 1 & $\mathrm{X}^{2}$ count & $\mathrm{X}^{2}$ table \\
\hline Leaf widht $\left(\mathrm{mm}^{2}\right)$ & $11.345-$ & $22.054-$ & 2 & 3 & 9.352 & 9.487 \\
& $32.708(2)$ & $36.936(3)$ & & & & \\
Leaf shape & Lanceolate (1) & Lanceolate (1) & 1 & 1 & - & - \\
Leaf surface & Pilosus (2) & Pilosus (2) & 3 & 3 & - & - \\
\hline
\end{tabular}

Note: The value of $X^{2}$ count $>X^{2}$ table means there is a correlation. The value of $X^{2}$ count $<X^{2}$ table means there is no correlation (Level 5\%, df: 4)

The shapes of leaves in both locations were uniform, Lanceolate (score 1). Suh et al. (2000) have exposed that laseolate leaves are better in light distribution in smaller leaf areas, the photosynthesis rates are also higher compared to wider leaves and oval leaves. Pigeon pea leaves are compound leaves. Moreover, single leaves and leaflets on compound leaves are sometimes difficult to distinguish because of the similarity of characteristics between the two, especially if the leaves are large and almost like single leaves. Maintang et al. (2014) have uncovered that pigeon pea leaves are trifoliate (Figure 2).

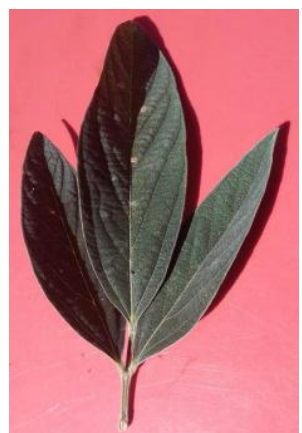

Figure 2. Lanceolate leaf shape of black pigeon pea
The surface of pigeon pea leaves in both locations was uniform, belonging to pubescent leaves (score 3). Diversity of the surfaces of pigeon pea leaves was no longer found. Chisquare analysis was only performed on leaf width characters and the results did not show a correlation with leaf width.

Dendrogram analysis of leaf morphology in Pringapus and Klopoloro 1 was carried out by grouping because the leaves of pigeon pea found in both areas appeared to have similar characteristics in shape and surface. The samples in Pringapus had nearly similar diversity level with the samples found in Klopoloro 1. This small diversity was merely caused by differences in leaf width characters.

\section{Flower mophology}

The basic color of pigeon pea in both locations was ivory (score 1). The colors in the RHS were given codes, in group 1 from A to D. Maintang et al. (2014) have remarked that the crown of pigeon pea flower is yellow or light brown. The secondary color of pigeon pea flowers found in both locations was also uniform, namely Red (score 1). The red color in the RHS was included in 45A group. According to Maintang et al. (2014), there 
is an orange red flag on the back part of the pigeon pea flower. Sharma et al. (2011) have added that some purple or red lines can be formed on pigeon pea flowers. Scars on the pattern of streaks found in both locations had sparse streaks (score 3 ). This means that the lines on the crown are small in number (Figure 3).

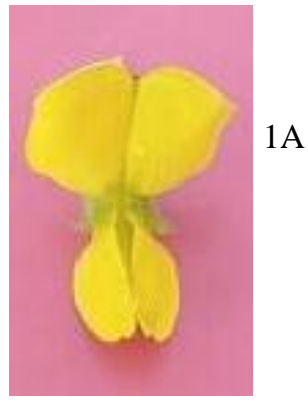

a

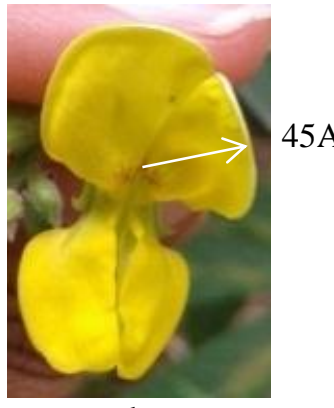

$b$
Figure 3. Ivory base color of pigeon pea flower (a), red secondary color of pigeon pea flower (b). In RHS color cart: 1A (part of yellow-red), 45A (part of yellow-red color).

\section{Pod morphology}

The color of pigeon pea pods in Pringapus was dominated by dark purple (score 4), while in Klopoloro 1, it was dominated by green (score 1). In RHS, dark purple was indicated by group 187A and green was specified by group 144B (Figure 4). Table 3 of Chi-square analysis presents $X^{2}$ count (14.863) > $\mathrm{X}^{2}$ table (9.487). According to Khoiriyah et al. (2018) and Gitiara et al. (2019), diffent place affects the phenotypic character of a plant such as pod color, seed coat color and etc. This shows that location correlates with the color of the pod and different location results in differences in the pod color.

The forms of pigeon pea pods found in both locations did not experience diversity. All samples had cylindrical shapes (score 2). On the words of Gitiara et al. (2019), the shape of the pigeon pea pod is straight and some are crescentshaped. The surface of pods in both locations was also uniform, which was hairy (Pubescent) (score 2). According to Sheahan (2012), the surface of the pigeon pea pod is covered by fine hairs.

Table 3. The diversity of morphological characters of pigeon pea pods in Pringapus and Klopoloro 1

\begin{tabular}{lcccccc}
\hline \multirow{2}{*}{ Character } & \multicolumn{2}{c}{ Location } & \multicolumn{2}{c}{ Score } & \multicolumn{2}{c}{ Chi-square analysis } \\
\cline { 2 - 7 } & Pringapus & Klopoloro 1 & Pringapus & Klopoloro 1 & $\mathrm{X}^{2}$ count & $\mathrm{X}^{2}$ table \\
\hline Pod color & Dark purple & Green & 4 & 1 & 14.863 & 9.487 \\
Pod shape & Cylindrical & Cylindrical & 2 & 2 & - & 9.487 \\
Pod surface & Pubescent & Pubescent & 2 & 2 & - & 9.487 \\
$\begin{array}{l}\text { Number of seeds } \\
\text { per pod (seeds) }\end{array}$ & $2-6$ & $5-7$ & 5 & 5 & 3.667 & 9.487 \\
& & & & & & \\
\hline
\end{tabular}

Note: The value of $\mathrm{X}^{2}$ count $>\mathrm{X}^{2}$ table means there is a correlation. The value of $\mathrm{X}^{2}$ count $<\mathrm{X}^{2}$ table means there is no correlation (Level 5\%, df: 4)

The number of seeds per pod in both locations were dominated by a score of 5 (Very much), $>6$ seeds per pod. Krisnawati (2005) and Saxena et al. (2010) have mentioned that the average number of seeds per pod of pigeon pea is $2-9$ seeds. Table 3 of Chi-square analysis demonstrates $\mathrm{X}^{2}$ count (3.667) $<X^{2}$ table (9.487). This shows that location influences the number of seeds per pod of pigeon pea.

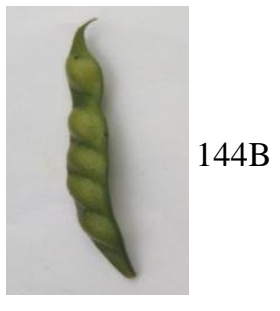

a

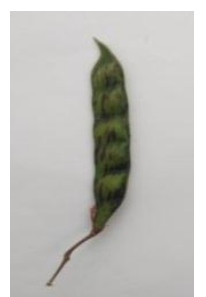

b
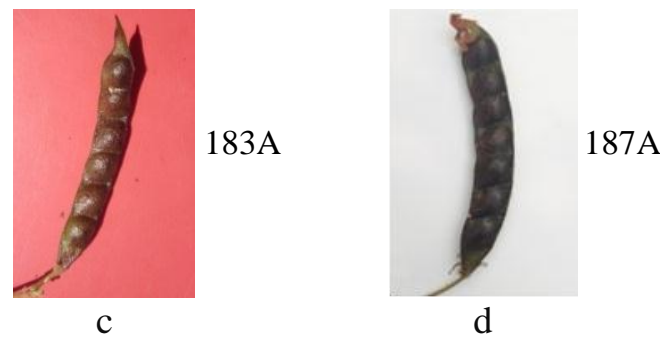

Figure 4. Green pod of pigeon pea (a), mixed pod of pigeon pea (b), dark pod of pigeon pea (c) and dark purple pod of pigeon pea (d). In RHS color cart: 144B (part of turquoise-green colour), 183A (part of brown-grey color), 187A (part of brown-grey color).

Chi-square analysis was only performed on the character of the pod color and number of seeds per 
pod. The dendrogram analysis of pod morphology of pigeon pea found in Pringapus grouped the pods because they had similar characters in shape and surface, while the analysis of pod morphology in Klopoloro 1 grouped the pods because they had similar characteristics in pod shape, pod surface and the number of seeds per pod.

\section{Seed morphology}

The motif of pigeon pea seed coat color in Pringapus was dominated by a score of 4 . This motif is a combination of spotted and dotted patterns on the surface of the seeds. Dotted pattern was represented by red dots which were sreading on the seed coat. Speckled pattern was characterized by a collection of red dots spreading on the seed coat. The red dots that are clustered look like patches yet rather thick. Meanwhile, the motif of coat color of pigeon pea seed found in Klopoloro 1 was dominated by a score 3 (speckled). According to Maintang et al. (2014), pigeon pea seeds have a plain or sometimes speckled color motif. Based on the results of chisquare analysis, the values of $\mathrm{X}^{2}$ count $(6.818)<$ $\mathrm{X}^{2}$ table (9.487). This means that place does not influence the seed coat color motif.
The color of seed coat base of pigeon pea found in Pringapus was similar, which was gray (score 3). Gray in the RHS was characterized by 197A group. The color of seed coat base of pigeon pea found in Klopoloro 1 was dominated by purple, shown by group 187A in the RHS. According to Sheahan (2012), the color of pigeon pea seed is various, from light to dark brown. Table 4 of Chi-square analysis portrays $\mathrm{X}^{2}$ count (10.909) > $X^{2}$ table (9.487). According to Khoiriyah et al. (2018), Yuniastuti et al. (2018), Delfianti et al. (2019) and Gitiara et al. (2019), different place affects the phenotypic character of a plant. This finding confirms that place puts effect on the color of seed coat base of pigeon pea.

The secondary color of seed coat of pigeon pea in Pringapus was uniform, reddish-brown (a score of 2). Reddish-brown in the RHS was indicated by $200 \mathrm{D}$ code. The secondary color of seed coat of pigeon pea in Klopoloro 1 was dominated by dark purple (a score of 5), indicated by code 202A. The results of Chi-square analysis verifies $\mathrm{X}^{2}$ count $(15)>\mathrm{X}^{2}$ table (9.487). This discloses that place influences the secondary color of seed coat.

Table 4. The diversity of morphological characters of pigeon pea seed in Pringapus and Klopoloro 1

\begin{tabular}{|c|c|c|c|c|c|c|}
\hline \multirow{2}{*}{ Character } & \multicolumn{2}{|c|}{ Location } & \multicolumn{2}{|c|}{ Score } & \multicolumn{2}{|c|}{ Chi-square analysis } \\
\hline & Pringapus & Klopoloro 1 & Pringapus & Klopoloro 1 & $\mathrm{X}^{2}$ count & $\mathrm{X}^{2}$ table \\
\hline $\begin{array}{l}\text { Seed coat color } \\
\text { motif }\end{array}$ & $\begin{array}{l}\text { Mottled and } \\
\text { specked }\end{array}$ & Speckled & 4 & 3 & 6.818 & 9.487 \\
\hline $\begin{array}{l}\text { Seed coat base } \\
\text { color }\end{array}$ & Grey & Purple & 3 & 4 & 10.909 & 9.487 \\
\hline $\begin{array}{l}\text { Seed coat } \\
\text { secondary color }\end{array}$ & Reddish-brown & Dark purple & 2 & 5 & 15. & 9.487 \\
\hline Seed shape & Globular & Globular & 2 & 2 & 5.04 & 9.487 \\
\hline
\end{tabular}

The shape of the pigeon pea seeds in both locations was mostly rounded (globular/peashaped) (score 2). Maintang et al. (2014) have discovered that pigeon pea seeds are round or oval. The presence of hilum pigeon pea seeds at $\mathrm{T} 1$ and $\mathrm{T} 2$ did not experience diversity. All samples were found to have marks of seed sticking. Table 4 of Chi-square analysis demonstrates value $\mathrm{X}^{2}$ count $(5.04)<\mathrm{X}^{2}$ table (9.487).

The dendrogram analysis of seed morphology in Pringapus grouped the seeds because they had the same characteristics of basic color, secondary color and shape. According to (Manuswamy et al., 2014), the color of pigeon pea seeds are similar because they have identical genotype. Whereas, in Klopoloro 1, the seeds were grouped because they had matching basic color and secondary color. The samples of pigeon pea seeds found in Pringapus had a smaller diversity value than those found in Klopoloro 1. This is due to the diversity of seed shapes of pigeon pea in Klopoloro 1.

\section{Dendrogram of all morphological characters}

Identification of sample grouping was based on the overall morphological characters of pigeon peas in Pringapus and Klopoloro 1, with all 
variables observed in each character (stem, leaf, The results of the analysis are presented in pod and seed). The UPGMA method was applied. dendrogram (Figure 5 and Figure 6).

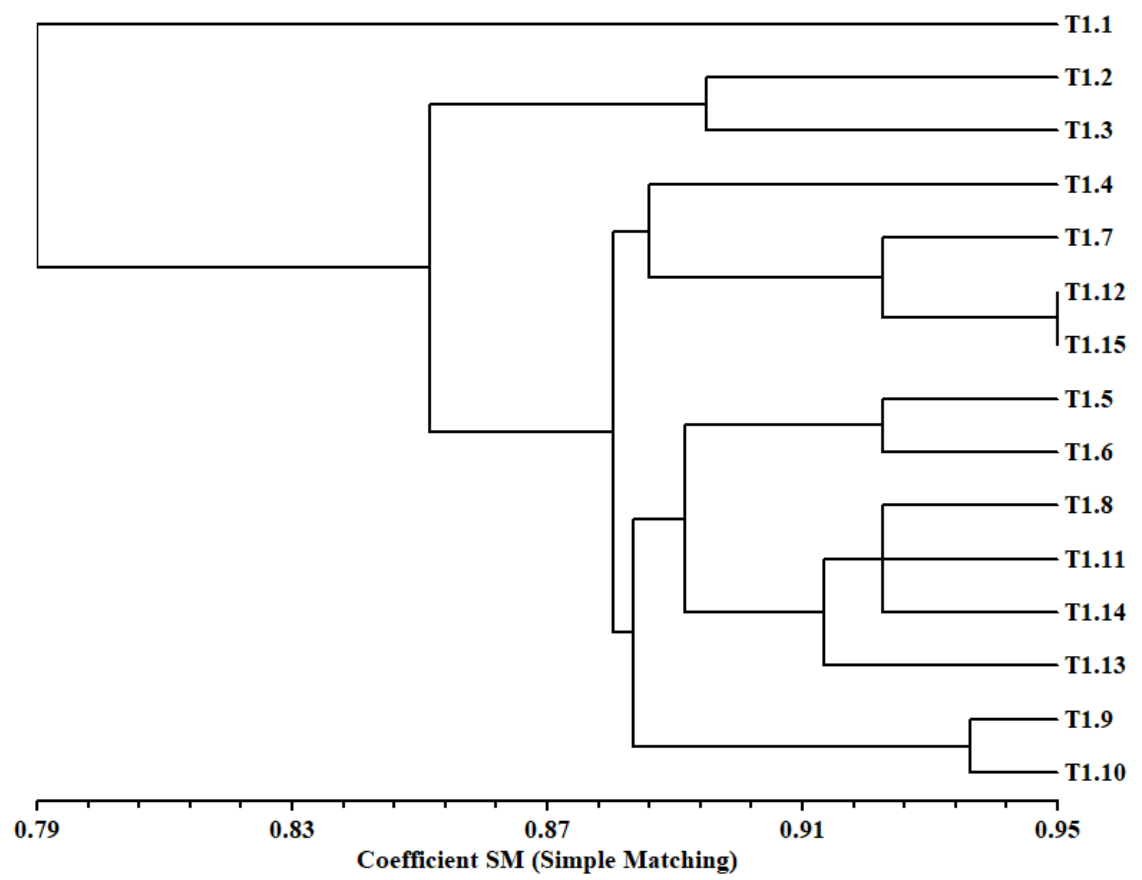

Figure 5. Dendrogram of grouping of samples in Pringapus based on all morphological characters

Note: T1.1-T1.15 = sample 1-15 of pigeon pea in Pringapus

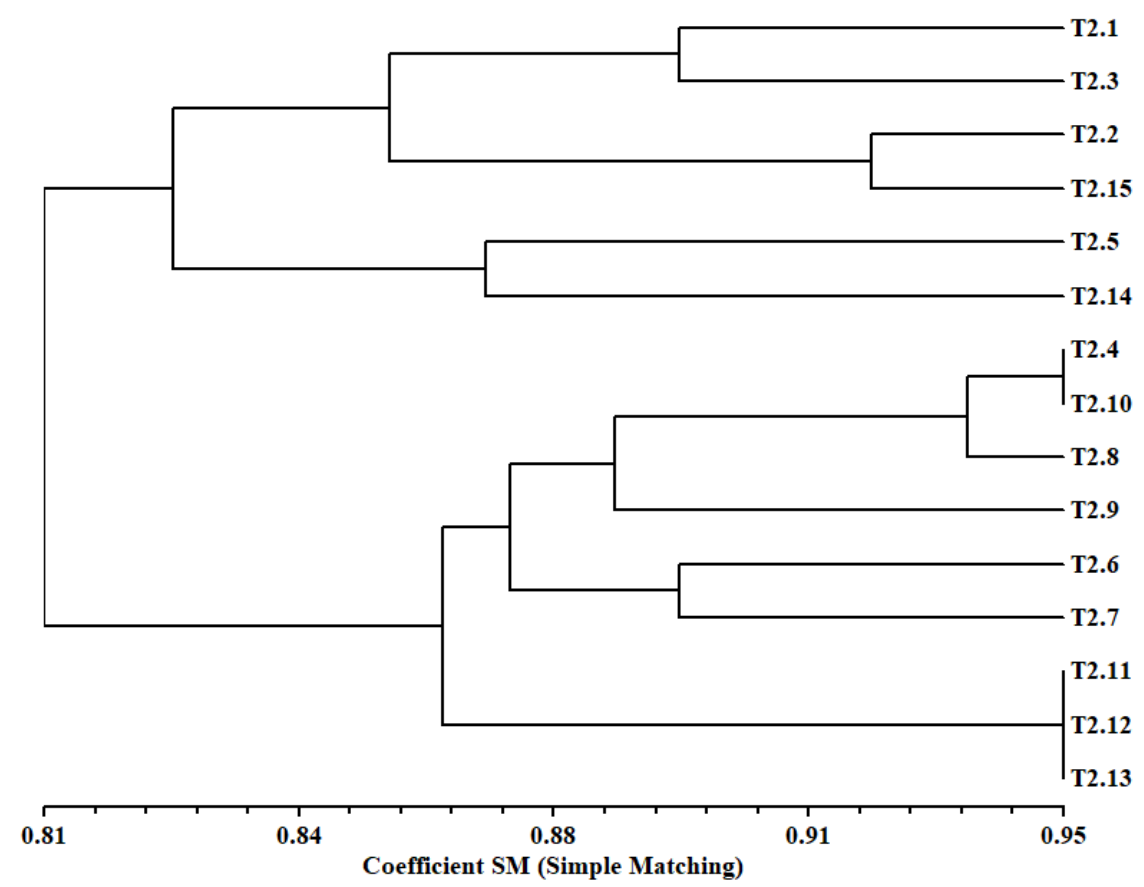

Figure 6. Dendrogram of samples grouping in Klopoloro 1 based on all morphological characters

Note: T2.1-T2.15 = sample $1-15$ of pigeon pea in Klopoloro 1 
Figure 5 shows the grouping of samples in Pringapus based on the overall morphology (stems, leaves, flowers, pods and seeds). The similar coefficient value was from 0.79 to 0.95 (79\% to $95 \%$ ). The coefficient of dissimilarity formed was $0.16(16 \%)$. The samples in Pringapus were grouped because they had differences in the number of branches and stem thickness in stem character, leaf width in leaf character, pod color and number of seeds per pod in pod character and the motif of seed coat color in seed character.

Figure 6 presents the grouping of samples in Klopoloro 1 based on the overall morphological characters. The similarity coefficient value was forme, from 0.81 to 0.95 ( $81 \%$ to $95 \%$ ). The coefficient of dissimilarity was $0.14(14 \%)$. The samples in Klopoloro 1 were grouped because they had differences in plant height, branch number and stem thickness in stem characters, leaf width in leaf characters, pod color in pod characters, seed coat color motif and seed shape in seed characters. The samples in Klopoloro 1 had a smaller diversity value than the samples in Pringapus.

\section{CONCLUSIONS}

Based on the results of the research, this study concludes several points. The similiarity of the coefficient value of pigeon peas in Pringapus ranged from $79 \%$ to $95 \%$, while the similarity of the coefficient value of pigeon peas in Klopoloro 1 varied from $81 \%$ to $95 \%$. The population of pigeon peas in Pringapus was more uniform than the population in Klopoloro 1. Thus, it is projected that the dominant flower pollination in Pringapus was self-pollination (autogamy), while the pollination of pigeon pea flowers in Klopoloro 1 was dominated by cross-pollination (alogamy).

\section{REFERENCES}

Adjei-Nsiah, S. (2012). Role of Pigeonpea Cultivation on Soil Fertility and Farming System Sustainability in Ghana. International Journal of Agronomy, 2012, 1-8. https://doi. org/10.1155/2012/702506

Bettencourt, E., Konopka, J., Damania, A. B., \& International Board for Plant Genetic Resources. (1989). Food legumes: arachis, cajanus, cicer, lens, lupinus, phaseolus, pisum, psophocarpus, vicia and vigna. IBPGR.
Retrieved from https://www.bioversityinterna tional.org/e-library/publications/detail/1i-food -legumes/

BPS Gunungkidul. (2015). Average Rainfall Gunungkidul. Retrieved July 17, 2019, from https://gunungkidulkab.bps.go.id/

Burns, M. J., Edwards, K. J., Newbury, H. J., Ford-Lloyd, B. V., \& Baggott, C. D. (2001). Development of simple sequence repeat (SSR) markers for the assessment of gene flow and genetic diversity in pigeonpea (Cajanus cajan). Molecular Ecology Notes, 1(4), 283 285. https://doi.org/10.1046/j.1471-8278.2001 .00109.x

Cisanet. (2015). Policy And Structural Arrangements Affecting the Global Market Opportunities For Malawi's Pigeon Peas and Pigeon Peas Products - Market Access-Key For Sustainable Development (Civil Soci, Vol. 1, No. 1). Lilongwe: Civil Society Agriculture Network. Retrieved from https://www.chris tianaid.org.uk/sites/default/files/2016-06/Pige on\%20Peas\%20Policy\%20Brief-1.pdf

Cook, B. G., Pengelly, B. C., Brown, S. D., Donnelly, J. L., Eagles, D. A., Franco, M. A., ... Schultze-Kraft, R. (2005). Tropical forages: An interactive selection tool. Retrieved from https://cgspace.cgiar.org/han dle/10568/33575

Darcan, O. N., \& Badur, B. Y. (2012). Student Profiling on Academic Performance Using Cluster Analysis. Journal of E-Learning \& Higher Education, 2012, 8. https://doi.org/10. 5171/2012.622480

Dayal, S., Lavanya, M., Devi, P., \& Sharma, K. K. (2003). An efficient protocol for shoot regeneration and genetic transformation of pigeonpea [Cajanus cajan (L.) Millsp.] using leaf explants. Plant Cell Reports, 21(11), 1072-1079. https://doi.org/10.1007/s00299-0 03-0620-y

Delfianti, M. N. I., Yuniastuti, E., \& Cahyani, V. R. (2019). Propagation and growth of persimmon (Diospyros kaki L.) in Indonesia. IOP Conference Series: Earth and Environ mental Science, 250, 012037. https://doi.org/ $10.1088 / 1755-1315 / 250 / 1 / 012037$

Ersam, T., Fatmawati, S., \& Fauzia, D. N. (2018). 
New Prenylated Stilbenes and Antioxidant Activities of Cajanus cajan (L.) Millsp. (Pigeon pea). Indonesian Journal of Chemistry, 16(2), 151-155. Retrieved from https://jurnal.ugm.ac.id/ijc/article/view/21158

Fu, Y., Zu, Y., Liu, W., Efferth, T., Zhang, N., Liu, X., \& Kong, Y. (2006). Optimization of luteolin separation from pigeonpea [Cajanus cajan (L.) Millsp.] leaves by macroporous resins. Journal of Chromatography $A$, 1137(2), 145-152. https://doi.org/10.1016/J. CHROMA.2006.08.067

Gitiara, E. W., Yuniastuti, E., \& Nandariyah. (2019). Growth and development of pigeon pea (Cajanus cajan) on the differences of Fitosan concentration. IOP Conference Series: Earth and Environmental Science, 250, 012097. https://doi.org/10.1088/1755-1315/25 0/1/012097

IBPGR. (1983). International Board For Plant Genetic Resources. 1-60. Retrieved from https://cgspace.cgiar.org/handle/10568/45742

Irawan, B., Kartika, P. (2008). Karakterisasi dan Kekerabatan Kultival Padi Lokal Di Desa Rancakalong, Kecamatan Rancakalong, Kabupaten Sumedang. Seminar Nasional PTTI, 21-23. Bandung. Retrieved from http://pustaka.unpad.ac.id/archives/46293

Khoiriyah, N., Yuniastuti, E., \& Purnomo, D. (2018). Genetic diversity of pigeon pea (Cajanus cajan (1.) Millsp.) based on molecular characterization using randomly amplified polymorphic DNA (RAPD) markers. IOP Conference Series: Earth and Environmental Science, 129, 012016. https:// doi.org/10.1088/1755-1315/129/1/012016

Krisnawati, A. (2005). Prospek Serta Pencandraan Sifat Kualitatif Dan Kuantitatif Kacang Gude (Cajanus cajan L. Millsp.). Buletin Palawija, O(9), 1-10. Retrieved from http://ejurnal.lit bang.pertanian.go.id/index.php/bulpa/article/v iew/8597

Kundu, R., Dasgupta, S., Biswas, A., Bhatta charya, A., Pal, B. C., Bandyopadhyay, D., ... Bhattacharya, S. (2008). Cajanus cajan Linn. (Leguminosae) prevents alcohol-induced rat liver damage and augments cytoprotective function. Journal of Ethnopharmacology, 118(3), 440-447. https://doi.org/10.1016/j.jep.

\subsubsection{0}

Maintang., Hanifa, A. P., Rivana, A. (2014). Potensi Kacang Gude Sebagai Komponen Diversifikasi Pangan. Prosiding Seminar Hasil Penelitian Tanaman Aneka Kacang Dan Umbi, 917-924. Retrieved from http://balit kabi.litbang.pertanian.go.id/wp-content/uploa ds/2015/05/917-924_Maintang-1.pdf

Manuswamy, S., Lokesha, R., Dharmaraj, P.S., Yamanura., \& Diwan, J. (2014). Morphological characterization and assessment of genetic diversity in minicore collection of pigeonpea [Cajanus Cajan (L.) Millsp.]. Electronic Journal of Plant Breeding, 5(2), 179-186. Retrieved from http://www.ejplant breeding.org/index.php/EJPB/article/view/11 1

Mengesha, M. (1979). Genetic Resources Activities at ICRISAT. Indian J. PI. Genet. Resources, 1(1-2), 47-57. Retrieved from http://oar.icrisat.org/2058/1/IndJouPIGenRes1 _1-2_49-58_1988.pdf

Niveditha, T. M. V, Suneetha, G., Aruna, L. V, Arundhati, A., \& Surekha, C. (2012). Invitro Regeneration Via Multiple Shoot Induction From Immature Embryos Of Pigeonpea (Cajanus cajan). International Journal of Advanced Biotechnology and Research, 3(4), 841-846. Retrieved from https://pdfs.semantic scholar.org/d844/d67ac5788b3416ae3d9ca7c 81fd9995d6d1d.pdf

Odeny, D. A. (2007). The potential of pigeonpea (Cajanus cajan (L.) Millsp.) in Africa. Natural Resources Forum, 31(4), 297-305. https://doi. org/10.1111/j.1477-8947.2007.00157.x

Porter, M. A., \& Bidlack, J. E. (2011). Morphology, Biomass, and Vessel Diameter of Pigeon Pea Subjected to Water Stress. Communications in Soil Science and Plant Analysis, 42(19), 2334-2343. https://doi.org/ 10.1080/00103624.2011.605491

Primiani, C. N., \& Pujiati, P. (2016). Charac teristics of Pigeon Pea (Cajanus cajan) Isoflavones Daidzein in Blood on Ovarian And Mammary Tissue Structure Rat Female. Proceeding Biology Education Conference: Biology, Science, Enviromental, and Learning, 13(1), 593-597. Retrieved from https://jurnal. uns.ac.id/prosbi/article/view/5844 
Purwanto, I. (2007). Mengenal Lebih Dekat Leguminoseae. Yogyakarta: Kanisius.

Reddy, L. J., Upadhyaya, H. D., Gowda, C. L. L., \& Singh, S. (2005). Development of core collection in pigeonpea [Cajanus cajan (L.) Millspaugh] using geographic and qualitative morphological descriptors. Genetic Resources and Crop Evolution, 52(8), 1049-1056. https://doi.org/10.1007/s10722-004-6152-7

Saxena, K. B., Ravishankar, K., Kumar, V., Kp, S., \& Srivastava, R. K. (2010). Vegetable Pigeonpea-a High Protein Food for all Ages. Information Bulletin No. 83. Patancheru 502 324, Andhra Pradesh, India: International Crops Research Institute for the Semi-Arid Tropics. $124 \mathrm{pp}$. Retrieved from http://oar. icrisat.org/195/1/315-09_IB83_Part_II_Veg_ Pigeonpea_Ricipes.pdf

Sharma, S., Agarwal, N., \& Verma, P. (2011). Pigeon pea (Cajanus cajan L.): A Hidden Treasure of Regime Nutrition. Journal of Functional And Environmental Botany, 1(2), 91-101. https://doi.org/10.5958/j.2231-1742.1 .2 .010

Sheahan, C. (2012). Plant Guide Pigeonpea Cajanus cajan (L.) Millsp. Retrieved from http://www.dpi.nsw.gov.au/_data/assets/pdf_ file/00

Silim, S. N., Mergeai, G., \& Kimani, P. M. (2001). Status and Potential of Pigeonpea in Eastern and Southern Africa. proceedings of a regional workshop, 12-15 Sep2000, Nairobi Kenya. B5030 Gembloux, Belgium: Gembloux Agri cultural University; and Patancheru 502 324, Andhra Pradesh, India: International Crops Research Institute forthe Semi-Arid Tropics. $232 \mathrm{pp}$. Retrieved from http://agropedia.ii tk.ac.in/sites/default/files/CO\%200015.pdf

Suh, S. K., Cho, Y., Park, H. K., \& Scott, R. A. (2000). Gene Action and Heritability of Leaf and Reproductive Characteristics in Soybean. Breeding Science, 50(1), 45-51. https://doi. org/10.1270/jsbbs.50.45

Utami, R., Widowati, E., \& Purwandari, Y. (2015). Karakterisasi Kaldu Nabati Kedelai Hitam (Glycine soja), Kacang Gude (Cajanus cajan, Mills) dan Biji Saga (Adenanthera pavonina, Linn) Melalui Fermentasi Koji Moromi. Jurnal Teknologi Hasil Pertanian,
8(1), 30-36. Retrieved from https://jurnal.uns. ac.id/ilmupangan/article/view/12792

Varshney, R. K., Chen, W., Li, Y., Bharti, A. K., Saxena, R. K., Schlueter, J. A., ... Jackson, S. A. (2012). Draft genome sequence of pigeonpea (Cajanus cajan), an orphan legume crop of resource-poor farmers. Nature Biotechnology, 30(1), 83-89. https://doi.org/ $10.1038 /$ nbt.2022

Waheed, A., Hafiz, A., Qadir, G., Murtaza, G., Mahmood, T., Ashraf, M., \& Kashmir, J. (2006). Effect Of Salinity On Germination, Growth, Yield, Ionic Balance And Solute Composition Of Pigeon Pea (Cajanus cajan (L.) Millsp). Pakistan Journal of Botany (Pakistan), 38,(4), 1103-1117. Retrieved from https://s3.amazonaws.com/academia.edu.docu ments/30936549/PJB38\%284\%291103.pdf?re sponse-content-disposition=inline $\% 3 \mathrm{~B} \% 20$ filename\%3DEffect_of_salinity_on_germinat ion_growth.pdf\&X-Amz-Algorithm=AWS4HMAC-SHA256\&X-Amz-Credential=AKIAI WOWYYGZ2Y53UL3A\%2F20200225\%2Fu s-east-1\%2Fs3\%2Faws4_request\&X-AmzDate $=20200225 \mathrm{~T} 015428 Z \& X-A m z-E x p i r e s$ $=3600 \& X-A m z-S i g n e d H e a d e r s=h o s t \& X-A m$ z-Signature $=0533373301$ aaf $888 \mathrm{c} 09 \mathrm{~d} 4 \mathrm{cc} 0 \mathrm{~d} 92$ 473109fbba878f38a54f9cd13251f492c644d

Worku, W., \& Demisie, W. (2012). Growth, light interception and radiation use efficiency response of pigeon pea (Cajanus cajari) to planting density in Southern Ethiopia. Journal of Agronomy, 11(4), 85-93. https://doi.org/ 10.3923/ja.2012.85.93

Wu, N., Fu, K., Fu, Y.-J., Zu, Y.-G., Chang, F.R., Chen, Y.-H., ... Gu, C.-B. (2009). Antioxidant Activities of Extracts and Main Components of Pigeonpea [Cajanus cajan (L.) Millsp.] Leaves. Molecules, 14(3), 1032-1043. https://doi.org/10.3390/molecules14031032

Yuniastuti, E., Anggita, A., Nandariyah, \& Sukaya. (2018). Local durian (Durio zibethinus murr.) exploration for potentially superior tree as parents in Ngrambe District, Ngawi. IOP Conference Series: Earth and Environmental Science, 142, 012029. https:// doi.org/10.1088/1755-1315/142/1/012029

Yuniastuti, E., Parjanto, Yulianingsih, E., \& Delfianti, M. N. I. (2018). Cytogenetic and karyotype analysis of sapodilla (Achras 
zapota). Bulgarian Journal of Agricultural Science, 24(3), 421-426. Retrieved from https://www.agrojournal.org/24/03-11.pdf

Yuniastuti, E, Wardani, N. C., \& Nandariyah. (2016). The effect of explant type and 6-
Benzyl adenine (BAP) in sapodilla (Achras zapota) micropropagation. American Journal of Biochemistry and Biotechnology, 12(4), 206-213. https://doi.org/10.3844/ajbbsp.2016. 206.213 